\title{
Contents of Volume 115 (2000)
}

\author{
Authors and Titles \\ I6I (Mar.) ADAMS, CHARLES S. (Whittier Coll.). Guest Column. The Real Small World(s) \\ 34I (May) ANDREW, DUDLEY (Yale Univ). The "Three Ages" of Cinema Studies and the \\ Age to Come (The Changing Profession) \\ I085 (Oct.) ARAC, JONATHAN (Univ. of Pittsburgh, Pittsburgh). Truth (Convention Mis- \\ cellany) \\ 195 (Mar.) BOWLES, BRETT (Iowa State Univ.). Poetic Practice and Historical Paradigm: \\ Charles Baudelaire's Anti-Semitism \\ I66 (Mar.) CORNISH, ALISON (Univ. of Michigan, Ann Arbor). A Lady Asks: The Gender \\ of Vulgarization in Late Medieval Italy \\ I I 3 (Oct.) DINGLEDINE, DON (Univ. of Wisconsin, Oshkosh). "The Whole Drama of the \\ War": The African American Soldier in Civil War Literature (Convention \\ Miscellany) \\ 33 (Jan.) FELSKI, RITA (Univ. of Virginia). Nothing to Declare: Identity, Shame, and the \\ Lower Middle Class \\ I084 (Oct.) FRYE, SUSAN (Univ. of Wyoming). Abstract of "Screening the Queen: Elizabeth \\ out of Hollywood by Popular Genres" (Convention Miscellany) \\ I053 (Oct.) GERMANO, WILLIAM (Routledge). Getting It Published (The Book Market) \\ I032 (Oct.) GILMAN, SANDER L. (Univ. of Chicago). Learning a Foreign Language in a \\ Monolingual World (The Changing Profession) \\ IO4I (Oct.) GRAFF, GERALD (Univ. of Illinois, Chicago). Scholars and Sound Bites: The \\ Myth of Academic Difficulty (The Changing Profession) \\ 292 (May) GRASS, GÜNTER. "To Be Continued ...”/ „Fortsetzung folgt . . “ (Nobel Lec- \\ ture 1999) \\ 20 (Jan.) HITCHCOCK, PETER (Graduate Center and Baruch Coll., City Univ. of New \\ York). They Must Be Represented? Problems in Theories of Working-Class \\ Representation \\ 3 Io (May) ISER, WOLFGANG (Univ. of Constance and Univ. of California, Irvine). Do I \\ Write for an Audience? (Correspondents Abroad) \\ 9 (Jan.) KAPLAN, CORA (Univ. of Southampton). Introduction. Millennial Class \\ 6o (Jan.) KASSANOFF, JENNIE A. (Barnard Coll.). Extinction, Taxidermy, Tableaux Vi- \\ vants: Staging Race and Class in The House of Mirth \\ I 108 (Oct.) KENNEDY, JENNIFER T. (Yale Univ.). Mourning at the Jubilee Celebration of \\ the Declaration of Independence (Convention Miscellany) \\ I 24 (Oct.) LEE, MAURICE S. (Univ. of California, Los Angeles). Writing through the War: \\ Melville and Dickinson after the Renaissance (Convention Miscellany) \\ 1103 (Oct.) LYNCH, DEIDRE (State Univ. of New York, Buffalo). Homes and Haunts: \\ Austen's and Mitford's English Idylls (Convention Miscellany) \\ (C) 2000 BY THE MODERN LANGUAGE ASSOCIATION OF AMERICA.]
}


1072 (Oct.) MARCUS, LEAH S. (Vanderbilt Univ.). Confessions of a Reformed Uneditor (II) (Convention Miscellany)

330 (May) MEHLMAN, JEFFREY (Boston Univ.). Un Amour de Hahn: Of Literature and Life (Theories and Methodologies)

975 (Oct.) MENKE, RICHARD (Univ. of Georgia). Telegraphic Realism: Henry James's $I n$ the Cage

1084 (Oct.) MINER, EARL (Princeton Univ.). Introductory Remarks (Convention Miscellany)

I006 (Oct.) MORRISSON, MARK, and JACK SELZER (Penn State Univ., University Park) Documenting Cultures of Modernism: Selections from Tambour (Little-Known Documents)

1063 (Oct.) MUELLER, JANEL (Univ. of Chicago). "To My Very Good Brother the King of Scots": Elizabeth I's Correspondence with James VI and the Question of the Succession (Convention Miscellany)

I 29 (Oct.) RISS, ARTHUR (Univ. of Rhode lsland). Abstract of "The Art of Discrimination: The Marble Faun, 'Chiefly about War Matters, and the Aesthetics of Race" (Convention Miscellany)

1077 (Oct.) ROSE, MARY BETH (Univ. of Illinois, Chicago). The Gendering of Authority in the Public Speeches of Elizabeth I (Convention Miscellany)

285 (May) SAID, EDWARD W. (Columbia Univ.). Presidential Address 1999: Humanism and Heroism

I I 7 (Oct.) SAMET, ELIZABETH D. (United States Military Acad.). "Adding to My Book and to My Coffin": The Unconditional Memoirs of Ulysses S. Grant (Convention Miscellany)

I 30 (Oct.) SCHECKEL, SUSAN (State Univ. of New York, Stony Brook). Abstract of "Remembering a Nation Divided: War, Tourism, and the Making of the Modern Citizen" (Convention Miscellany)

46 (Jan.) SCHOCKET, ERIC (Hampshire Coll.). "Discovering Some New Race": Rebecca Harding Davis's "Life in the Iron Mills" and the Literary Emergence of Working-Class Whiteness

SELZER, JACK. See MORRISSON, MARK, and JACK SELZER.

I089 (Oct.) SMITH, BARBARA HERRNSTEIN (Duke Univ.). Netting Truth (Convention Miscellany)

318 (May) SMITH, BRUCE R. (Georgetown Univ.). Premodern Sexualities (Theories and Methodologies)

99 I (Oct.) STATEN, HENRY (Univ of Washington). Is Middlemarch Ahistorical?

I082 (Oct.) SUZUKI, MIHOKO (Univ. of Miami). Abstract of "Elizabeth, Gender, and the Political Imaginary of Seventeenth-Century England" (Convention Miscellany)

Iog6 (Oct.) TRUMPENER, KATIE (Univ. of Chicago). Memorics Carved in Granite: Great War Memorials and Everyday Life (Convention Miscellany)

75 (Jan.) WARD, CYNTHIA (Univ. of Hawai'i, Mānoa). From the Suwanee to Egypt, There's No Place like Home

315 (May) WATERS, LINDSAY (Harvard Univ. Press). A Modest Proposal for Preventing the Books of the Members of the MLA from Being a Burden to Their Authors, Publishers, or Audiences (The Book Market)

1083 (Oct.) WATKINS, JOHN (Univ. of Minnesota, Twin Cities). Abstract of "Gloriana's Secrets: The Restoration Discovery of Elizabeth's Private Life" (Convention Miscellany)

I8 I (Mar.) WICKMAN, MATTHEW (Univ. of California, Los Angeles). The Allure of the Improbable: Fingal, Evidence, and the Testimony of the "Echoing Heath"

I 129 (Oct.) YOUNG, ELIZABETH (Mount Holyoke Coll.). Abstract of "Border States and Boundary Crossings: Rethinking Civil War Literature" (Convention Miscellany) 


\section{Conference on the Future of Doctoral Education (Oct.)}

ABRAM, MICHAEL E. (Cohen, Weiss and Simon). Graduate Student Assistants and Collective Bargaining: What Model?

BUTLER, TODD (Univ. of North Carolina, Chapel Hill). Rethinking the Academic and Nonacademic Divide

COHEN, WALTER (Cornell Univ.). The Economics of Doctoral Education in Literature

DELBANCO, ANDREW (Columbia Univ). What Should $P h D$ Mean?

DeNEEF, A. LEIGH (Duke Univ.). Discussion Group Notes from "The Purpose of the PhD as Preparation for Employment"

DOODY, MARGARET ANNE (Univ. of Notre Dame). Is Literature Dead?

DUBROW, HEATHER (Univ, of Wisconsin, Madison). Workshop on Placement Services

FERGUSON, MARGARET (Univ. of California, Davis). Come Tell Me How You Live

FOSTER, FRANCES SMITH (Emory Univ.). Not So Final Reflections, but a Beginning

FRIEDRICHSMEYER, SARA (Univ. of Cincinnati). Cultural Studies and the Future of Doctoral Education

GAYLORD, MARY M. (Harvard Univ.). On the Outside Looking In: Some Thoughts about the MA Degree

GIORDANO, MICHAEL J. (Wayne State Univ). Revaluing the Master's Degree

GRAFF, GERALD (Univ. of llinois, Chicago). Two Cheers for Professionalizing Graduate Students

GUILLORY, JOHN (New York Univ). The System of Graduate Education GUNDERMANN, CHRISTIAN (Cornell Univ.). The Place and Placement of Foreign Nationals in English, Foreign Languages, and Comparative Literature GUTIERREZ, NANCY A. (Arizona State Univ., Tempe). An Identity Crisis? HOHENDAHL, PETER UWE (Cornell Univ.). After Three Decades of Crisis: What Is the Purpose of a PhD Program in Foreign Languages? . Introduction

HULT, DAVID F. (Univ, of California, Berkeley). Playing by the Numbers: A Different Perspective on the Job Market

IRWIN, ROBERT McKEE (Tulane Univ.). A Participant's Report

LADD, BARBARA (Emory Univ.). An Informal Report to the Emory English Department

MARKS, ELAINE (Univ. of Wisconsin, Madison). Reflections and Recommendations

MIGNOLO, WALTER D. (Duke Univ.). The Role of the Humanities in the Corporate University

NELSON, CARY (Univ. of llinois, Urbana). Graduate Studies and the Job Market PORTER, LAURENCE M. (Michigan State Univ.). A Teacher-Training Course for Graduate Students in Literature and Culture

ROYSTER, JACQUELINE JONES (Ohio State Univ., Columbus). Shifting the Paradigms of English Studies: Continuity and Change

SHUMWAY, NICOLAS (Univ. of Texas, Austin). Preparing Graduate Students to Teach in the Major: Two Modest Proposals

STIMPSON, CATHARINE R. (New York Univ.). Myths of Transformation: Realities of Change

THOMPSON, JAMES (Univ. of North Carolina, Chapel Hill). Report on the Session "The Status of Literary History"

WEISBUCH, ROBERT (Woodrow Wilson National Fellowship Foundation). The Humanities at Work 


\section{Miscellaneous}

5 I5 (Dir.) Association Statistics

$45^{I}$ (Dir.) Committees and Commissions

5 I9 (Dir.) A Concise Guide to Activities and Services

488 (Dir.) Constitution

473 (Dir.) Contributors to the 1999 MLA International Bibliography

498 (Dir.) Delegate Assembly Bylaws

Departmental Administrators

800 (Dir.) Four-Year Colleges and Universities

822 (Dir.) Two-Year Colleges

943 (Dir.) Directory of Useful Addresses

5 I5 (Dir.) Distribution of Members

462 (Dir.) Divisions and Discussion Groups

281 (May) Editor's Column

969 (Oct.) Editor's Column

836 (Dir.) Ethnic Studies Programs

858 (Dir.) Fellowships and Grants

89 (Jan.) Forum

209 (Mar.) Forum

I 32 (Oct.) Forum

445 (Dir.) Governance Structure: Officers, Executive Council, Delegate Assembly

533 (Dir.) Honorary Fellows

532 (Dir.) Honorary Members

850 (Dir.) Humanities Research Centers

797 (Dir.) In Memoriam

839 (Dir.) Language and Area Programs

534 (Dir.) Members

518 (Dir.) Members of the Executive Council, 1986-2000

529 (Dir.) The MLA Staff

516 (Dir.) The One Hundred Ten Presidents

850 (Dir.) Organizations for Independent Scholars

482 (Dir.) Policies for Divisions, Discussion Groups, and Allied and Affiliate Organizations

501 (Dir.) Prizes

475 (Dir.) Procedures for Organizing Meetings at the MLA Convention

I20 (Jan.) Professional Notes and Comment

236 (Mar.) Professional Notes and Comment

394 (May) Professional Notes and Comment

877 (Dir.) Professional Notes and Comment

1298 (Oct.) Professional Notes and Comment

495 (Dir.) Proposed Amendments to the Constitution

352 (May) Report of the Executive Director

852 (Dir.) Reports of the Regional Modern Language Associations

842 (Dir.) Women's Studies Programs 


\section{Three Books in One}

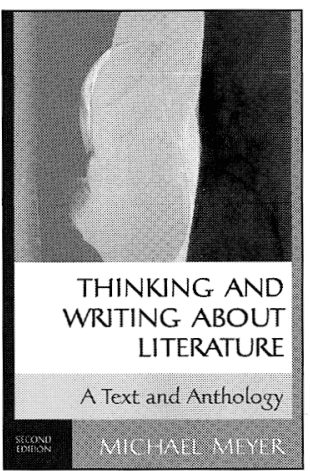

Available Now!
THINKING AND WRITING ABOUT LITERATURE A Text and Anthology

Second Edition

Michael Meyer, University of Connecticut

2001/PAPER/1200 PAGES

COMPANION WEB SITE: WWW.bedfordstmartins.com/bedlit

Thinking and Writing About Literature combines three books in one - a composition text, an introduction to literature, and a thematic anthology - all working together to help students become better academic writers, better literary readers.

"The strength of Thinking and Writing About Literature lies in the fact that it puts writing first; it asks students to approach literature as writers

(rather than starting first as readers and then realizing that they also need to write something)."

- Shari Horner, Shippensburg University

\section{“A Literary Gold Mine”}

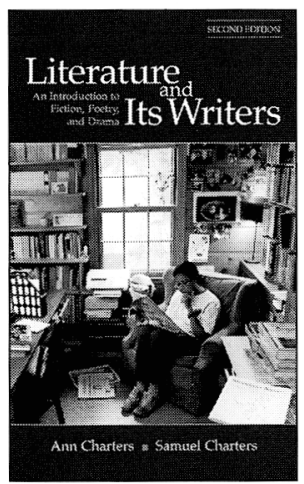

Available Now!

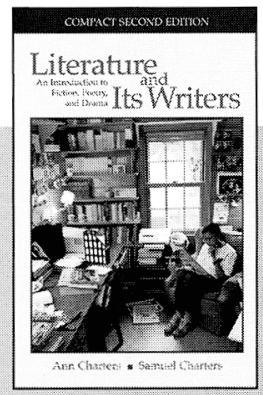

Azailable Now!
LITERATURE AND ITS WRITERS

\section{NEW!}

Second Edition

Ann Charters, University of Connecticut

Samuel Charters

\section{1/PAPER/2200 PAGES}

INSTRUCTOR'S MANUAL.

COMPANION WEB SITE: www.bedfordstmartins.com/charters

With its unique emphasis on how authors talk about what they do, this introductory anthology lets the words of the writers guide students in their exploration of the many ways to read, think, and write about literature.

"I not only find Literature and Its Writers to be an excellent instructional text, but I feel that my students are spending a semester with a literary gold mine. Many of them discover this and read far more selections than are assigned for the course."

\section{- Jane Whorton, Pearl River Community College}

Also available:

LITERATURE AND ITS WRITERS

NEW!

An Introduction to Fiction, Poetry, and Drama

Compact Second Edition

Ann Charters, University of Connecticut

Samuel Charters

2001/PAPER/1600 PAGES

COMPANION WEB SITE: wWw.bedfordstmartins.com/charters 


\section{Forthcoming in the \\ January issue of PMLA}

\section{World Spans}

Special Topic:

Globalizing Literary Studies

\section{Introduction by Giles Gunn}

Essays that test the circumference of languages and literatures

Criticism in Translation:

"The Language of Two Shores" 